\title{
Growth of Arthrobacter globiformis in soil observed by fluorescent antibody and ELISA techniques
}

\author{
E. Y. Mansoor and T. R. G. Gray \\ Author for correspondence: T. R. G. Gray. Tel: +44 1206 873316. Fax: +44 1206873416. \\ e-mail: grayt@essex.ac.uk
}

Department of Biology, University of Essex, Wivenhoe Park, Colchester CO4 3SQ, UK

\begin{abstract}
The growth and survival of Arthrobacter globiformis (NCIMB 10683) in a wheatfield and a sand-dune soil were investigated by introducing rod-shaped cells on the surface of microscope slides into the soil. Slides were recovered and stained with fluorescent antibodies. In the wheatfield soil, new microcolonies of considerable size were observed on or around both soil particles and fungal hyphae throughout the incubation period of $48 \mathrm{~d}$. In both sterile and non-sterile wheatfield soil, the majority of the rods reverted to cocci after 2 weeks incubation. In the sand-dune soil, cells did not grow and only a few were found after $\mathbf{4 8} \mathrm{d}$. Growth of A. globiformis in the wheatfield soil was also investigated using a direct soil inoculation technique. Soil samples were recovered after different incubation periods and cells extracted using a centrifugation method. The number of cells in extracts was estimated using ELISA and direct count techniques. In the latter technique, extracted cells were double-stained with fluorescent antibodies and ethidium bromide. Growth took place in both sterile and non-sterile wheatfield soil. The introduced rods reverted to cocci after a few days, as on the slides. However, cells introduced directly into soil grew faster than those introduced on slides.
\end{abstract}

Keywords: soil microbiology, Artbrobacter globiformis, cell enumeration, fluorescent antibodies

\section{INTRODUCTION}

Many workers have studied growth and activity of soil bacteria, including Artbrobacter spp., by introducing laboratory-grown bacterial cultures into sterile soil and determining viable cell numbers by conventional plating techniques after incubation of the soil (Robinson et al., 1965; Salonius et al., 1970; Lowe \& Gray, 1973a, b). The information obtained using this approach is misleading because of the differences between sterilized and natural soils as media for microbial growth. Sterilization, in addition to eliminating the viable population, alters the physical, chemical and nutritional properties of the soil. Furthermore, the types and amounts of nutrients available for bacterial growth in soil depend partly on the presence of other micro-organisms, their products and dead remains.

Thompson et al. (1990, 1992), used plate culture procedures to investigate the survival of two ecologically

Abbreviations: FITC, fluorescein isothiocyanate; RhITC, rhodamine isothiocyanate. distinct bacteria (Flavobacterium and Arthrobacter) introduced into sterile and non-sterilized unplanted and rhizosphere soils both in laboratory soil microcosms and in the field. However, they found difficulties in discriminating the organism under study from the rest of the soil microflora. It was also impossible, by conventional plate count techniques, to appreciate the spatial interrelationships between micro-organisms within the soil, or to examine the morphology (rods, cocci or mycelia) of the arthrobacters in soil.

The organism under study can be distinguished from the rest of the soil microflora by using fluorescent antibodies. Siala \& Gray (1974) investigated both the occurrence of native cells and the growth and germination of vegetative and spore forms of Bacillus subtilis in sterile and non-sterile soil from the $A_{1}$ and $C$ horizons of a sand dune soil in this way.

The use of immunological techniques for quantitative autecological studies of micro-organisms in soil has received little attention. Development and evaluation of a procedure for the enumeration of a specific population in natural habitats using an immunofluorescence cell 
counting technique were reported by Bohlool \& Schmidt (1973) and Schmidt (1974). More recently, enzyme-linked immunosorbent assay (ELISA) has been developed for quantitative studies (Engvall \& Perlmann, 1971). The ELISA technique has been used successfully for the identification of Rbizobium strains (Kishinevsky \& Gurfel, 1980; Olsen et al., 1983; Fuhrmann \& Wollum, 1985) and reports indicated that the rhizobial numbers are estimated reliably by this assay in soil (Martensson \& Gustafsson, 1985; Nambiar \& Anjaiah, 1985). However, Lochner et al. (1988) reported some limitations of this assay for routine determination of legume inoculant quality.

The preparation of relatively specific antisera (Mansoor, 1992) to a number of Artbrobacter reference strains and the staining of both rod and coccoid forms of these strains with the same fluorescence intensity made it possible to distinguish the strain introduced into soil, either on the surface of sterile slides or added directly to the soil, from the rest of soil microflora. Thus, it became possible to study the location, growth and morphology of Artbobacter globiformis (NCIMB 10683) in the presence of a complete soil microflora, using both immunofluorescence and ELISA techniques. This is important, as $A$. globiformis is one of the commonest isolates from soil and its function is poorly understood. It was also possible to test predictions on the behaviour of this organism made from studies on its physiology in continuous culture.

\section{METHODS}

Soils. Soil samples were collected from the top $6 \mathrm{~cm}$ of a wheatfield (Brick House Farm, Peldon, Essex, UK; OS Map 168, TL 997154) and from an embryo sand dune (near Chapel of St Peter ad Vincula, Bradwell, Essex; OS Map 168, TM 031089). The wheatfield soil was a silty clay loam (Windsor series) with a $\mathrm{pH}$ of 6.5 which had been planted only with wheat for 30 successive years and had been regularly supplied with NPK fertilizers. The sand-dune soil ( $\mathrm{pH} 8.3$ ) came from an area of wind-blown sand and crushed shells just above the spring high-tide level and was colonized by Agropyron pungens and Carex arenaria.

The samples were sieved to remove large roots and twigs. The moisture content of each soil was determined and approximately $40 \mathrm{~g}$ of each soil were placed in each of several Petri dishes.

For the preparation of sterile soil, deionized water was added to double the moisture content. The soil was autoclaved for $30 \mathrm{~min}$ at $121^{\circ} \mathrm{C}$ on two separate occasions, with $24 \mathrm{~h}$ incubation at room temperature in between. After the second autoclaving, plates of soil were cooled to room temperature, by which time the water content had fallen to about field level. Soils were maintained at this level throughout the experiment by addition of sterile water following further decreases in weight.

Preparation of the inoculum. Artbrobacter globiformis NCIMB 10683 was grown on nutrient agar (Oxoid) in medical flat bottles at $25^{\circ} \mathrm{C}$ for $18 \mathrm{~h}$. The cells were harvested by centrifugation, washed four times in sterile deionized water and resuspended in $25 \mathrm{ml}$ deionized water in $100 \mathrm{ml}$ Erlenmeyer flasks. After dispersion of aggregates by stirring, the suspension was diluted with sterile deionized water to give an appropriate concentration of cells. The suspension was checked microscopically to confirm that cells were rod-shaped.

Contact slides. Clean, grease-free microscope slides were sterilized and inoculated by spreading $0.01 \mathrm{ml}$ of a suspension of rod-shaped cells over one side of the slide with a flame-sterilized needle. The slides were allowed to dry in sterile Petri dishes and then placed on the surface of soil samples with the inoculum in contact with the soil. This resulted in an inoculum of about $10^{3}-10^{4}$ cells $\mathrm{mm}^{-2}$. Inoculated slides were incubated in sterile and non-sterile wheatfield soil, and in sterile and non-sterile sand-dune soil at $15^{\circ} \mathrm{C}$. Controls of non-inoculated slides and slides inoculated with heat fixed cells were also used.

Recovery, staining and observation of slides. Triplicate slides were recovered from each treatment after varying periods of incubation. The slides were heat fixed, rinsed in PBS for $5 \mathrm{~min}$ and air dried. Gelatin-RhITC conjugate (Bohlool \& Schmidt, 1968) was allowed to flood the slide surface and dried as a film at $60^{\circ} \mathrm{C}$. The $A$. globiformis-specific antiserum $(0 \cdot 1 \mathrm{ml})$ at a dilution of $1: 20$ (antiserum:PBS) was added to the slide. The slides were incubated in a humid chamber for $1 \mathrm{~h}$ at $25^{\circ} \mathrm{C}$ and washed for $15 \mathrm{~min}$ before air drying. FITC-conjugated antirabbit serum was used at a dilution of $1: 20$ to stain the preparations, which were incubated and washed as before. The stained bacteria were covered with a mixture of a mountant (Mowiol) and an antifade agent ( $p$-phenylenediamine) $(1: 9)$ and a cover glass. Preparations were observed with a $\times 100$ oilimmersion lens, using non-fluorescent immersion oil, and viewed with a Leitz Dialux 20 microscope, fitted with a Ploemopak 2.4 (Leitz Instruments) under short-wavelength blue light. Fifty fields of view were observed on each slide, the fluorescent cells counted and the dimensions of 10 randomly selected cells in each field of view measured. The mean number of fluorescent cells and their biovolume per field of view were determined. Photographs were taken with a WILD MPS 55 photo automatic system (Leitz Instruments) on Kodak Ektachrome film (ASA 400).

Soil inoculation. Forty gram quantities of sterile and non-sterile wheatfield soil in Petri dishes were inoculated with appropriate concentrations of cell suspension prepared as before but in a small volume of water and mixed thoroughly with a sterile spatula to disperse the cells throughout the soil. The soils were incubated at $15{ }^{\circ} \mathrm{C}$.

Cell extraction. Triplicate Petri dishes were recovered from each treatment after different periods of incubation. A soil extraction procedure for bacteria based on that of Holben $e t$ al. (1988) and modified at the University of Aberdeen, UK (J. I. Prosser, personal communication) was used. The contents of each Petri dish (40 g soil) were combined with $150 \mathrm{ml} 0.1 \%$ $(\mathrm{w} / \mathrm{v})$ sodium deoxycholate $(\mathrm{pH} 7 \cdot 5)$ and $10 \mathrm{~g}$ acid-washed polyvinylpolypyrrolidone (Evans et al., 1972) and homogenized in a $500 \mathrm{ml}$ capacity Atomix blender for three $1 \mathrm{~min}$ intervals (with $1 \mathrm{~min}$ cooling on ice between each blending cycle). The homogenate was placed on ice to settle and transferred to a $250 \mathrm{ml}$ centrifuge bottle. The soil debris was pelleted by centrifugation at $1500 \mathrm{~g}$ for $10 \mathrm{~min}$ at $4{ }^{\circ} \mathrm{C}$. The supernatant (SN1) was transferred to a fresh $250 \mathrm{ml}$ centrifuge bottle and kept on ice for further treatment. The soil pellet was subjected to two more rounds of homogenization and centrifugation. The three supernatants obtained (SN1, SN2 and SN3) were combined and centrifuged at $10000 \mathrm{~g}$ for $30 \mathrm{~min}$ at $4{ }^{\circ} \mathrm{C}$. The bacterial pellet was washed twice in $200 \mathrm{ml} 0 \cdot 1 \%$ (w/v) sodium pyrophosphate and twice in $2 \%(\mathrm{w} / \mathrm{v})$ sodium hexametaphosphate ( $\mathrm{pH} 8.5$ ) by centrifugation at $10000 \mathrm{~g}$ for $30 \mathrm{~min}$ at $4{ }^{\circ} \mathrm{C}$. The bacterial pellet was suspended in $100 \mathrm{ml}$ TE buffer $(0.33 \mathrm{M}$ Tris $/ \mathrm{HCl}, \mathrm{pH} 8 \cdot 0+1 \mathrm{mM}$ EDTA $)$ and centrifuged as above. The supernatant was decanted and the final bacterial pellet weighed and suspended in $10 \mathrm{ml}$ Tris/sucrose/EDTA buffer $(\mathrm{pH} \mathrm{8.0)}$ in a $25 \mathrm{ml}$ capacity Erlenmeyer flask.

Enumeration of cells in extracts from soil. The extracted cell suspension was agitated to disperse the bacterial cells and serial 
dilutions $\left(10^{-1}-10^{-7}\right)$ were prepared. Portions $(0 \cdot 1 \mathrm{ml})$ of appropriate dilutions were spread over the surface of sterile peptone yeast extract agar (Goodfellow et al., 1968) in Petri dishes. Three plates were prepared at each dilution and all were incubated at $25^{\circ} \mathrm{C}$ for $10 \mathrm{~d}$. The mean numbers of bacteria developing were calculated and the number of viable bacteria per $g$ oven-dry soil determined.

Appropriate dilutions of extracted cell suspensions $(0.01 \mathrm{ml})$ were spread over exactly $1 \mathrm{~cm}^{2}$ area of new, unused microscope slides. Three slides were prepared at each dilution for each treatment. The preparations were dried at $45^{\circ} \mathrm{C}$ and stained using fluorescent antisera as above. The stained preparations were dried at room temperature and counter-stained with $0.1 \mathrm{ml}$ ethidium bromide solution $\left(0.2 \mathrm{mg} \mathrm{ml}^{-1}\right)$ for $3 \mathrm{~min}$. The slides were rinsed in deionized distilled water and dried. The preparations were mounted under cover slips and viewed with a Leitz Dialux 20 microscope, with either short-wavelength blue or green light. The number of green-fluorescing and redfluorescing cells occurring in 50 fields of view inside an oblong (area: $0.0004 \mathrm{~cm}^{2}$ ) marked on the eyepiece graticule on each slide were counted and the dimensions of 10 randomly selected fluorescent cells in each field of view measured. The number and biovolume of the cells per $g$ oven-dry soil was determined.

ELISA. Fifty-microlitre portions of appropriate dilutions of extracted cell suspensions prepared as above were placed in wells of a 96-well microtitre plate. An indirect ELISA procedure was used to estimate cell concentrations (Mansoor, 1992).

\section{RESULTS}

\section{Determination of a standard curve for ELISA tests on soil samples}

Plate counts and indirect-ELISA values obtained with serially diluted suspensions of 15 sterile wheatfield soil samples inoculated with $A$. globiformis were used to determine the correlation between $A_{450}$ values and plate counts and to construct a standard curve. Log cell numbers were plotted against $A_{450}$ values of three dilutions of each sample (Fig. 1). A highly significant

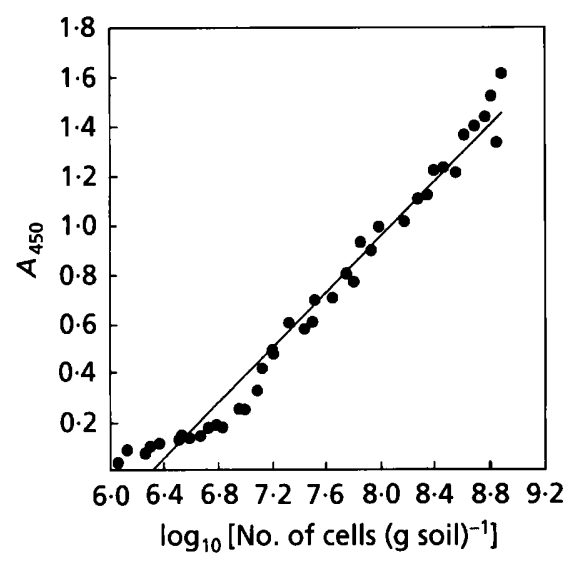

Fig. 1. Relation between indirect ELISA $A_{450}$ values and $\log _{10}$ viable cell number of $A$. globiformis NCIMB 10683 in presterilized, inoculated soil. Values obtained with 15 wheatfield soil samples were used to construct the curve $(y=0.568 x-3.584 ; r=0.98)$. All values represent the mean of triplicate samples.

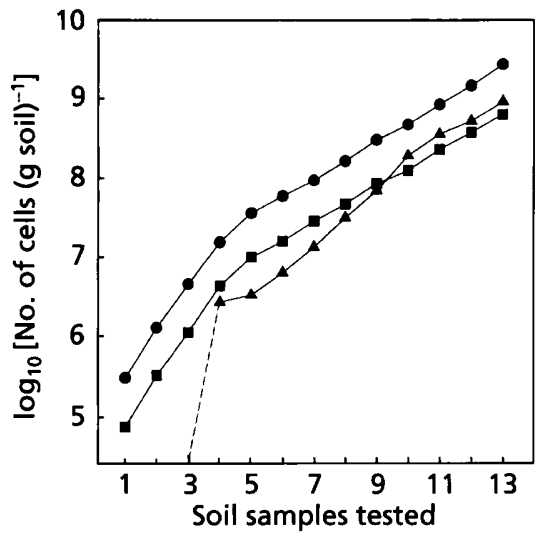

Fig. 2. Comparison of indirect ELISA and plate count estimates of A. globiformis NCIMB 10683 recovered from pre-sterilized wheatfield soils inoculated with different numbers of cells. Bacteria added to soil; $\boldsymbol{\Delta}$, ELISA estimates; $\boldsymbol{\square}$, plate count estimates.

$(P=0.001)$ linear relationship was obtained $(r=0.98)$ and analyses of variance indicated that the straight line was statistically a good fit when soil samples contained more than $10^{7}$ cells (g soil) ${ }^{-1}$.

The reliability of the curve for estimating cell numbers from indirect-ELISA values was tested with 13 sterile soil samples inoculated with different cell concentrations of A. globiformis. A comparison of indirect-ELISA estimates with plate counts of $A$. globiformis is shown in Fig. 2. Statistical analyses ( $t$-test) showed that there were no significant differences $(P=0.05)$ between the two counting methods when plate counts were in the range $10^{6}-10^{8}$ cells (g soil $)^{-1}$. The results also showed (Fig. 2) that it was not possible to detect $A$. globiformis cells using the indirect ELISA test when plate counts were below $10^{6}$ cells ( $\mathrm{g}$ soil $)^{-1}$. The standard curve was used in a comparison of the fate of rods of $A$. globiformis in sterile and non-sterile wheatfield soil.

\section{Growth of bacteria in non-sterile wheatfield soil}

Fate of bacteria on contact slides. Triplicate slides were recovered immediately after placing the slides in contact with the soil and at $6 \mathrm{~d}$ intervals for $48 \mathrm{~d}$. Biovolumes of the fluorescing cells were calculated (Fig. 3). The number and biovolume of cells dropped during the first $6 \mathrm{~d}$ of incubation. Examination of stained slides recovered at this stage indicated that some of the fluorescing cells were washed off the slides during the staining procedure (Fig. $4 a)$. There were also green haloes around sites of cell growth, suggesting that the cells were secreting antigenic materials and that cells had been lost during preparation. An increase in the number and biovolume of the fluorescing cells was observed after $12 \mathrm{~d}$ and continued to the 30th day, after which the number and biovolume of the cells rapidly declined. Stained slides recovered at and after $18 \mathrm{~d}$ showed microcolonies of considerable size formed on or around soil particles (Fig. 4b). Examination 


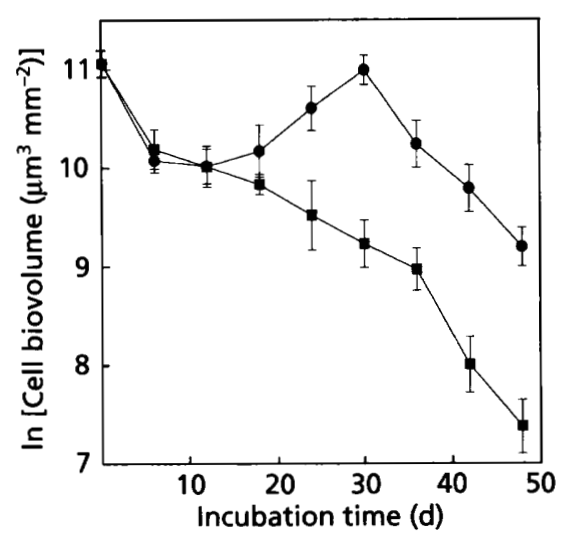

Fig. 3. Growth curves of $A$. globiformis NCIMB 10683 on contact slides in non-sterile wheatfield soil $(O)$ and dune sand (E) detected with fluorescent antibodies.

of slides recovered at and after $24 \mathrm{~d}$ showed the development of fungal hyphae and actinomycete mycelium; they also showed microcolonies of considerable size on or near fungal hyphae (Fig. 4c). Fewer microcolonies were associated with actinomycete mycelium. After $12 \mathrm{~d}$, at least $80 \%$ of the rods had reverted to cocci (Fig. 5).

Fate of bacteria added directly to soil. Triplicate soil samples were recovered immediately after adding bacteria and at weekly intervals for seven weeks. Bacteria were extracted from soil using the centrifugation extraction method and the biovolume of $A$. globiformis cells per $\mathrm{g}$ soil estimated using direct cell counts and ELISA techniques.

Agreement between fluorescent antibody and ELISA estimates was good. A twofold decrease in the biovolume of cells was observed during the first week of incubation, followed by a gradual 10 -fold increase that continued for 2 weeks, after which the biovolume of cells declined steadily to the end of the experiment (Fig. 6). Examination of stained slides of extracted cells recovered during the first week of incubation showed that the majority of cells were already coccoid.

\section{Growth of bacteria in non-sterile sand-dune soil}

The growth of $A$. globiformis in the non-sterile sand-dune soil was only investigated using the contact slide technique. A marked decrease in the biovolume of fluorescing cells was observed during the first $6 \mathrm{~d}$ of incubation and continued to the end of the experiment (Fig. 3). No growth was observed during the whole experiment. Stained slides recovered at and after $6 \mathrm{~d}$ of incubation showed that the majority of the fluorescing cells were dying or lysing cocci (Fig. 5). Fungal hyphae or actinomycete mycelium were very rare on the slides.

\section{Growth of bacteria in sterile wheatfield soil}

Fate of bacteria on contact slides. A. globiformis cells introduced on slides and placed in contact with the sterile wheatfield soil decreased in biovolume (as in the non-
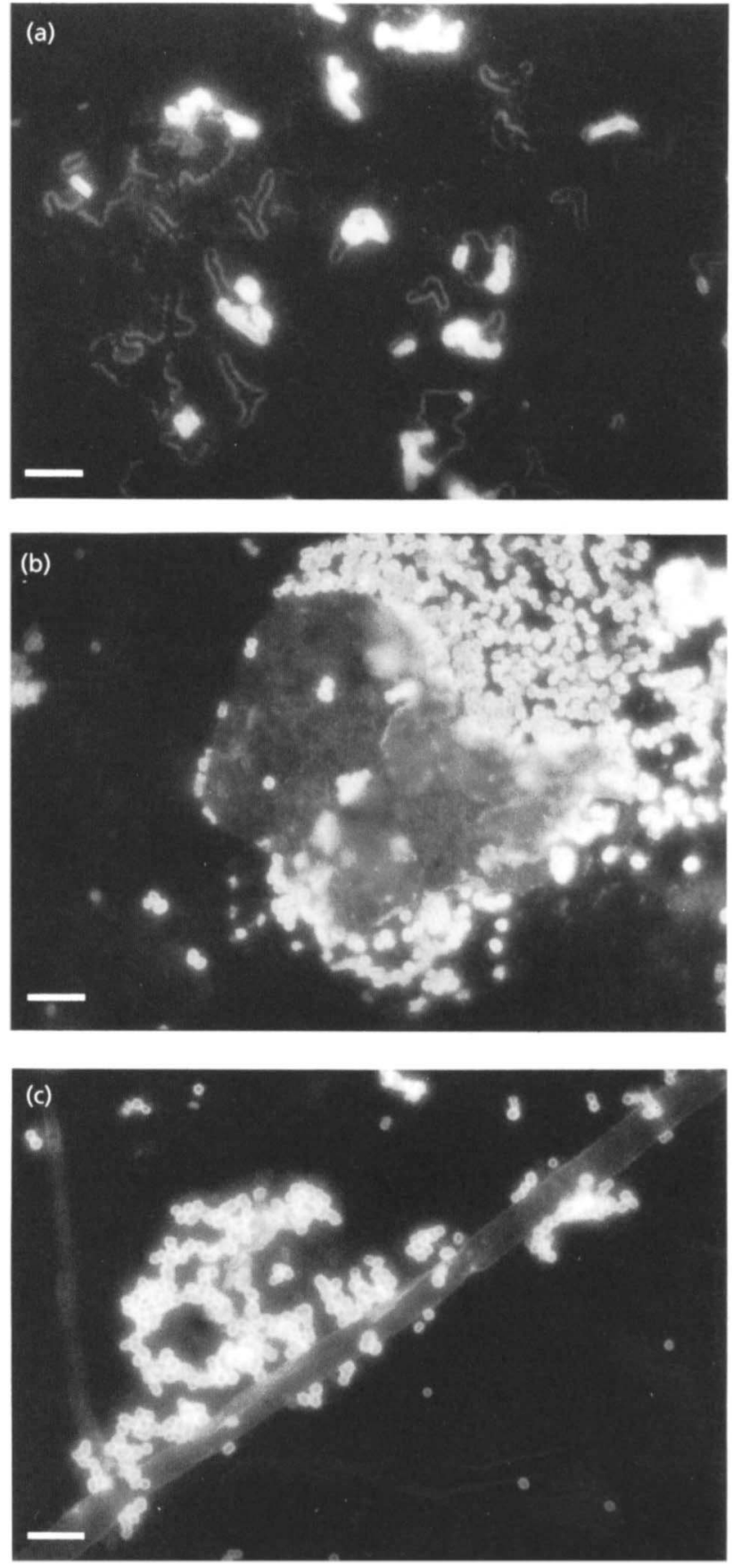

Fig. 4. Slides recovered from non-sterile wheatfield soil after various periods of incubation and stained with fluorescent antibodies. (a) Slide recovered after $6 \mathrm{~d}$ incubation, showing that $A$. globiformis NCIMB 10683 cells had been washed off during staining: the haloes left behind show the presence of residual, excreted antigenic material which had reacted with the antiserum. (b) Slide recovered after $18 \mathrm{~d}$ incubation, showing the growth of A. globiformis NCIMB 10683 as cocci in large colonies around a mineral soil particle. (c) Slide recovered after $24 \mathrm{~d}$ incubation, showing the growth of $A$. globiformis NCIMB 10683 as cocci on and near a fungal hypha. Bars, $5 \mu \mathrm{m}$. 


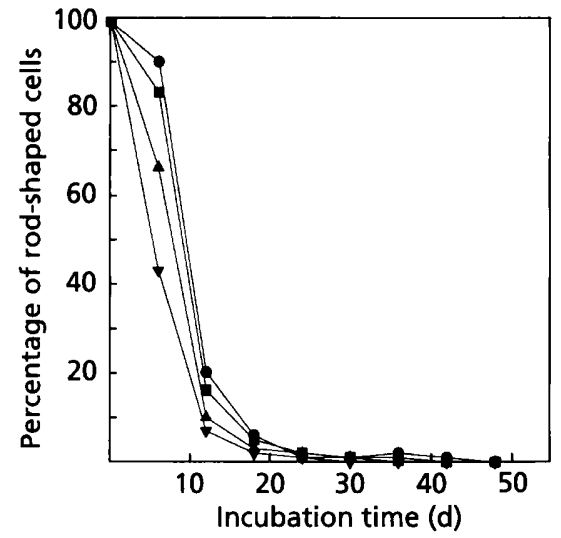

Fig. 5. Changes with time in the morphology of A. globiformis NCIMB 10683 cells on contact slides in sterile (O) and nonsterile $(\boldsymbol{\square})$ wheatfield soil and sterile $(\boldsymbol{\Delta})$ and non-sterile $(\boldsymbol{\nabla})$ dune sand.

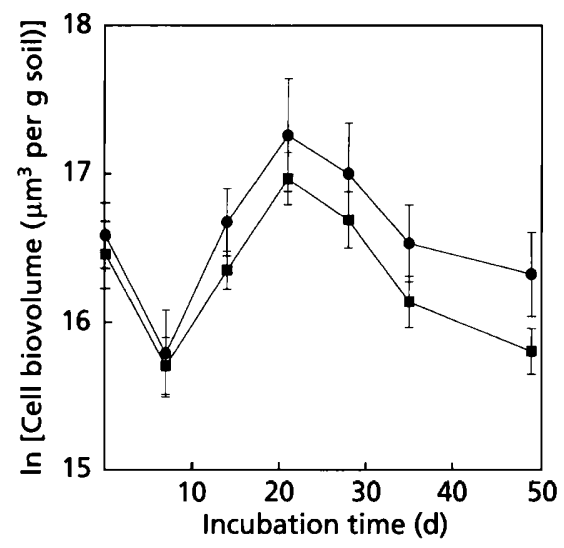

Fig. 6. Growth curves of A. globiformis NCIMB 10683 inoculated into non-sterile wheatfield soil. Based on estimates from ELISA (O) and fluorescent antibody methods ( $\square$ ).

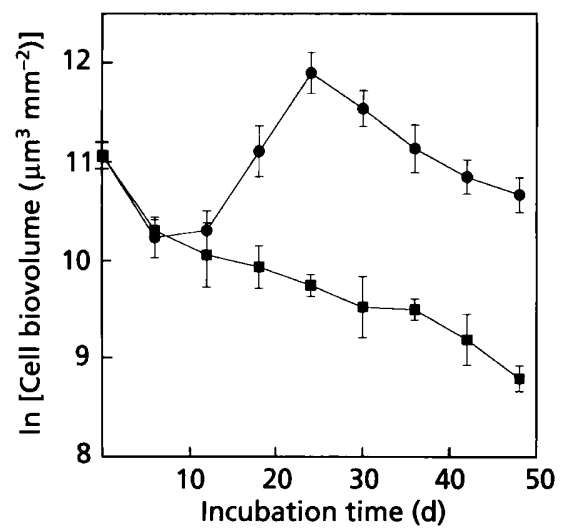

Fig. 7. Growth curves of A. globiformis NCIMB 10683 on contact slides in sterile wheatfield soil $(O)$ and dune sand $(\square)$ detected with fluorescent antibodies.

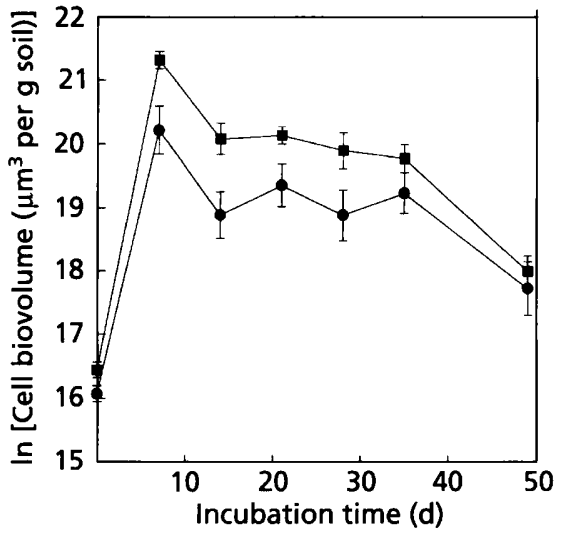

Fig. 8. Growth curves of A. globiformis NCIMB 10683 inoculated into sterile wheatfield soil. Based on estimates from ELISA (O) and flucrescent antibody methods ( $(\mathbf{O})$.

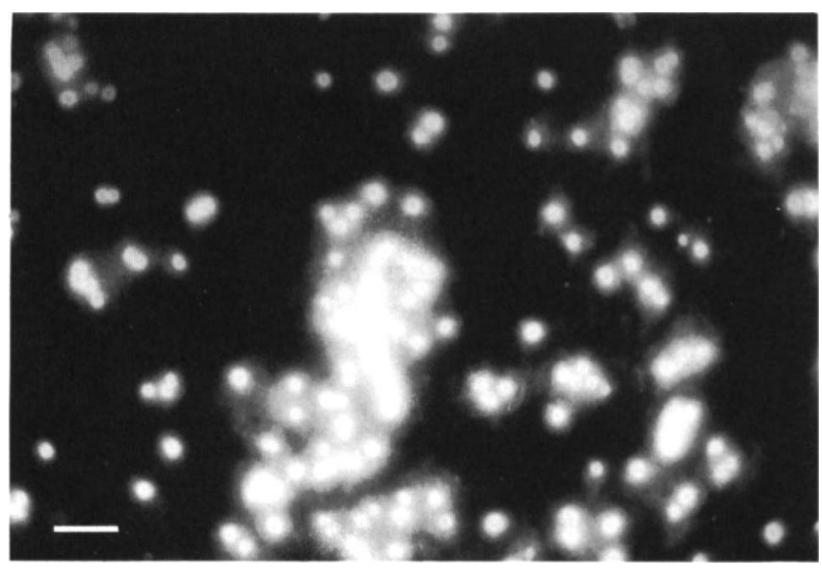

Fig. 9. A. globiformis NCIMB 10683 cells after $7 \mathrm{~d}$ growth in sterile wheatfield soil, showing the development of a myceloid cell as well as many cocci. Bar, $5 \mu \mathrm{m}$.

sterile soil) during the first $6 \mathrm{~d}$ of incubation (Fig. 7). However, an approximately 100 -fold increase in the biovolume of the fluorescing cells was observed during the next 2.5 weeks, after which it dropped steadily. As in the non-sterile soil, examination of stained slides recovered from the sterile soil at and after $18 \mathrm{~d}$ of incubation showed micro-colonies of considerable size formed on or around soil particles; the majority of the fluorescing cells were cocci (Fig. 5).

Fate of bacteria added to soil. In sterile soil, the introduced cells behaved differently from those introduced into non-sterile soil. A significant 200 -fold increase in the biovolume of the cells was observed during the first week of incubation, followed by a slight but significant decline during the second week (Fig. 8). Biovolumes measured between weeks 2 and 5 were not significantly different but a further significant decrease had taken place by week 7 . The majority of cells from samples recovered during the first week of incubation were cocci, but a few were myceloid (Fig. 9). Agreement between the two 
Table 1. Generation times of $A$. globiformis NCIMB 10683 in the sterile and non-sterile wheatfield soil, estimated during exponential phase, using soil inoculation and contact slide techniques

\begin{tabular}{|clcc|}
\hline Technique & Counting method & \multicolumn{2}{c|}{$\begin{array}{c}\text { Mean generation } \\
\text { time (h) }\end{array}$} \\
\cline { 3 - 4 } & & Sterile soil & $\begin{array}{c}\text { Non-sterile } \\
\text { soil }\end{array}$ \\
\hline \multirow{2}{*}{ Soil inoculation } & & 24 & 184 \\
& & 28 & 158 \\
& & Fluorescent antibody count & 243 \\
\hline
\end{tabular}

methods used to estimate cell numbers was good, but fluorescent antibody counts were slightly higher than ELISA estimates.

\section{Growth of bacteria in sterile sand-dune soil}

Growth of A.globiformis cells introduced into sterile sanddune soil was only investigated using the contact slide technique. Cells placed in contact with sterile sand-dune soil showed similar behaviour to the cells in non-sterile sand-dune soil. A marked decrease in the biovolume of the fluorescing cells was observed during the first $6 \mathrm{~d}$ and continued to the end of the experiment (Fig. 7). Stained slides recovered from this soil showed similar results to those from non-sterile soil.

\section{Generation times of cells in soil}

Table 1 shows the generation times of $A$. globiformis in sterile and non-sterile wheatfield soil. They were calculated only for the period of increase in biovolume from the data shown in Figs 3, 6, 7 and 8. Generation times varied between 24 and $243 \mathrm{~h}$, depending upon the growth conditions and methods of study. They were always shorter in sterile soil by up to a factor of 7 . They were also shorter when calculated from direct soil inoculation, rather than from contact slides, although this difference was less marked in non-sterile soils. Data from fluorescent antibody counts and indirect ELISA estimates were comparable.

\section{DISCUSSION}

Estimations of the biovolume of a particular species can be made both by counting cell numbers using fluorescent antibodies and by ELISA methods. However, ELISA was found to be insensitive when detecting cells in sterile soils and could not be used when populations fell below

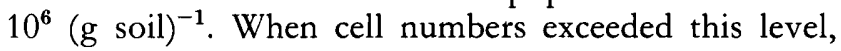
ELISA and fluorescent antibody results from soil samples containing a mixture of organisms correlated well. However, when there were differences they were not consistent: sometimes the ELISA estimates were higher and sometimes lower.

Ecological conclusions about bacteria should not be drawn from experiments on populations in pre-sterilized soil. The mean generation time for $A$. globiformis in the non-sterile wheatfield soil was substantially higher than in the sterile soil (Table 1), a result similar to that obtained for Rhizobium japonicum by Schmidt (1974). In unsterile soil, an approximately twofold decrease in biovolume occurred during the first week of incubation, followed by a gradual 10 -fold increase during the next 2 weeks. By contrast, in the sterile soil, a 200 -fold increase in biovolume was observed during the first week of incubation. Survival of inocula in non-sterile habitats is known to be adversely affected by predation and competition (Habte \& Alexander, 1977; Casida, 1980).

The maximum growth rate of $A$. globiformis NCIMB 10683 in continuous culture has been shown to be about $0.37 \mathrm{~h}^{-1}$, equivalent to a generation time of $2.7 \mathrm{~h}$ (Luscombe \& Gray, 1974). Luscombe \& Gray (1971, 1974) showed that the transformation of rods into cocci depended upon the growth rate of the culture and that rods were characteristic of rapidly growing cultures. On the basis of such data, a change from coccus to rod in the natural environments was predicted if the generation time was greater than $13.8 \mathrm{~h}$. The results obtained in the present study are consistent with this prediction. Direct observation of cells extracted from soil after one week of incubation showed that most of the rod-shaped cells in the inoculum had changed to cocci or short rods: they never reverted to rod forms, even though growth was occurring. This shows that cocci are not dormant forms but are the commonest growth form in soil for this organism.

The results obtained in the present study thus extend those obtained by Thompson et al. $(1990,1992)$ for Artbrobacter strain A109. In non-sterile soils, although marked decreases in the biovolume of $A$. globiformis cells were observed in the first week, division and formation of micro-colonies of considerable size on or around soil debris did occur in the next 2-3 weeks. The formation of micro-colonies was also observed around or near fungal hyphae and occasionally near actinomycete mycelium. However, the growth of $A$. globiformis cells was not conditional upon the growth and development of fungal hyphae, since their growth started well before fungal growth and observations on sterile soils showed similar large colonies of arthrobacters. This contrasts with the behaviour of Bacillus subtilis on contact slides in acidic 
sand-dune soil, when fungal growth was a precondition for bacterial growth (Siala \& Gray, 1974).

It has generally been assumed that contact slides change the environment of bacteria being studied in the soil and stimulate activity since they favour the condensation of water and provide a fresh and different physical surface for colonization. However, the use of both direct inoculation and inoculated contact slides in this study showed that contact slides actually slowed the rate of growth of bacteria, especially when they were in contact with otherwise sterile soil. Bacteria added directly to the soil will be in greater contact with nutrients, and oxygen diffusion to the cells may be restricted at slide surfaces: losses of cells from slides during preparation could also lead to inaccuracies.

Contact slides placed in sterile wheatfield soils induced the growth of a small number of myceloid cells. The formation of myceloid cells in a number of Artbrobacter strains in culture has been ascribed to increased osmotic stress (Deutch \& Perera, 1992): others have related it to vitamin deficiencies. It is not clear what is responsible for it in soil but it was relatively rare under the conditions of this experiment.

A. globiformis NCIMB 10683 was isolated from a sanddune soil planted with pine trees (Lowe \& Gray, 1972), and Lowe \& Gray (1973a) showed that it could grow in sterile alkaline dune soil from the $\mathrm{C}$ horizon. However, it failed to establish itself and died out in surface non-sterile alkaline dune sand in the present study. This may reflect the salt content of the sand used here which came from very close to the high-tide line.

\section{REFERENCES}

Bohlool, B. B. \& Schmidt, E. L. (1968). Non-specific staining; its control in immunofluorescence examination of soil. Science 162, 1012-1014.

Bohlool, B. B. \& Schmidt, E. L. (1973). A fluorescent antibody technique for determination of growth rates of bacteria in soil. Bull Ecol Res Comm 17, 336-338.

Casida, L. E. (1980). Death of Micrococcus luteus in soil. Appl Environ Microbiol 39, 1031-1034.

Deutch, C. E. \& Perera, G. S. (1992). Myceloid cell formation in Arthrobacter globiformis during osmotic stress. J Appl Bacteriol 72, 493-499.

Engvall, E. \& Perlmann, P. (1971). Enzyme-linked immunosorbent assay of immunoglobulin G. Immunochemistry 8, 871-874.

Evans, H. J., Koch, B. \& Klucas, R. (1972). Preparation of nitrogenase from nodules and separation into components. Methods Envymol 24, 470-476.

Fuhrmann, J. \& Wollum, A. G. (1985). Simplified enzyme-linked immunosorbent assay (ELISA) for routine identification of Rhizobium japonicum antigens. Appl Environ Microbiol 49, 1010-1013.

Goodfellow, M., Hill, I. R. \& Gray, T. R. G. (1968). Bacteria in a pine forest soil. In The Ecology of Soil Bacteria, pp. 500-515. Edited by T. R. G. Gray \& D. Parkinson. Liverpool: Liverpool University Press.

Habte, M. \& Alexander, M. (1977). Further evidence for the regulation of bacterial populations in soil by protozoa. Arch Microbiol 113, 181-183.

Holben, W. E., Jansson, J. K., Chelm, B. K. \& Tiedje, J. M. (1988). DNA probe method for the detection of specific micro-organisms in the soil bacterial community. Appl Environ Microbiol 54, 703-711.

Kishinevsky, B. \& Gurfel, D. (1980). Evaluation of enzyme-linked immunosorbent assay (ELISA) for serological identification of different Rhizobium strains. J Appl Bacteriol 49, 517-526.

Lochner, H. H., Strijdom, B. W., Kishinevsky, B. \& Steyn, P. L. (1988). Limitation of the enzyme-linked immunosorbent assay for routine determination of legume inoculant quality. $J$ Appl Bacteriol 64, 209-218.

Lowe, W. E. \& Gray, T. R. G. (1972). Ecological studies on coccoid bacteria in a pine forest soil. I. Classification. Soil Biol Biochem 4, 459-468.

Lowe, W. E. \& Gray, T. R. G. (1973a). Ecological studies on coccoid bacteria in a pine forest soil. II. Growth of bacteria introduced into soil. Soil Biol Biochem 5, 449-462.

Lowe, W. E. \& Gray, T. R. G. (1973b). Ecological studies on coccoid bacteria in a pine forest soil. III. Competitive interactions between bacterial strains in soil. Soil Biol Biochem 5, 463-472.

Luscombe, B. M. \& Gray, T. R. G. (1971). Effect of varying growth rate on the morphology of Artbrobacter. J Gen Microbiol 69, 433-434.

Luscombe, B. M. \& Gray, T. R. G. (1974). Characteristics of Artbrobacter grown in continuous culture. $J$ Gen Microbiol 82, 213-222.

Mansoor, E. Y. (1993). Immunological approaches to the ecology of Artbrobacter in soil. PhD thesis, University of Essex.

Martensson, A. M. \& Gustafsson, J. G. (1985). Competition between Rhizobium trifolii strains for nodulation, during growth in a fermenter, and in soil based inoculants, studied by enzyme-linked immunosorbent assay. J Gen Microbiol 131, 3077-3082.

Nambiar, P. T. C. \& Anjaiah, V. (1985). Enumeration of rhizobia by enzyme-linked immunosorbent assay (ELISA). $J$ Appl Bacteriol 58, 187-193.

Olsen, P. E., Rice, W. A., Stemke, G. W. \& Page, W. J. (1983). Strain specific serological techniques for the identification of Rbizobium meliloti in commercial alfalfa inoculants. Can J Microbiol 29, 225-230.

Robinson, J. B., Salonius, P. O. \& Chase, F. E. (1965). A note on the differential response of Arthobacter spp. and Pseudomonas spp. to drying soil. Can J Microbiol 11, 746-748.

Salonius, P. O., Robinson, J. B. \& Chase, F. E. (1970). The mutual growth of Arthrobacter globiformis and Pseudomonas fluorescens in gamma sterilised soil. Plant Soil 32, 316-326.

Schmidt, E. L. (1974). Quantitative autecological studies of microorganisms in soil by immunofluorescence. Soil Sci 118, 141-149.

Siala, A. \& Gray, T. R. G. (1974). Growth of Bacillus subtilis and spore germination in soil observed by a fluorescent antibody technique. J Gen Microbiol 81, 191-198.

Thompson, I. P., Cook, K. A., Lethbridge, G. \& Burns, R. G. (1990). Survival of two ecologically distinct bacteria (Flavobacterium and Artbrobacter) in unplanted and thizosphere soil. Soil Biol Biochem 22, 1029-1037.

Thompson, I. P., Young, C. S., Cook, K. A., Lethbridge, G. \& Burns, R. G. (1992). Survival of two ecologically distinct bacteria (Flavobacterium and Artbrobacter) in unplanted and rhizosphere soil: field studies. Soil Biol Biochem 24, 1-14.

Received 17 August 1994; accepted 29 September 1994. 